\title{
Dominance or Effectiveness? Which is More Important in Brand Personality Decisions?
}

\author{
By Oylum Korkut Altuna* \& F. Müge Arslan ${ }^{\dagger}$
}

In the post-modern age, consumers have developed strong relationships with brands as brands have become significant tools that are deliberately picked up by consumers to manifest their ideal self-image to others. Hence, one of the most crucial characteristics of a brand is its personality and the level of its congruence with its target market. Brand personality has become a widely-used element in brand positioning and communication strategies. In most academic studies, the dimensional structure of brand personality is assessed and the main personality trait with the highest score is accepted as the brand personality characteristic to be highlighted in marketing communication strategies. This study focuses on the effects of each dimension of brand personality on brand image, brand loyalty and willingness to recommend the brand to others in order to be able to determine which trait should be communicated in integrated marketing communications. The study was conducted on 4410 female respondents in Turkey. An online survey was applied. The results show that although the dominant brand personality trait was found to be a particular one; the most effective traits on brand loyalty, brand image and willingness to recommend the brand to others were completely different.

Keywords: Brand Personality, Brand Image, Brand Loyalty, Willingness to Recommend, Marketing Communication.

\section{Introduction}

The idea that brands have personalities like human beings and these personalities have become tools for consumers to express themselves is now well established in terms of both brand literature and marketing practices (Belk 1988, Swaminathan et al. 2009). Brand personality is one of the most important characteristic of a brand that aids in the creation of brand image. Brands and their associated images relate to "let consumers express who they are, what they are, where they are, and how they want to be viewed" (Graeff 1997: 50).

In order to take advantage of the utilities of the brand personality concept in full, it is crucial to understand the underlying mechanisms emerging under different circumstances and to identify other constructs "that provide more specific insights into which brand personality traits are going to matter to consumers" (Swaminathan et al. 2009).

Although there are a number of studies that focus on the measurement and the identification of the dimensional structure of brand personality, limited research has been concentrated on the predictive role of the construct on "key dependent variables in consumer behavior" (Sung and Kim 2010: 640). However, as with

\footnotetext{
*Associate Professor, Istanbul University, Turkey.

†Professor, Marmara University, Turkey.
} 
many other constructs developed and tested in brand literature which is particularly related to symbolic consumption, it is crucial to test brand personality in a practical context in order to model its specific function in consumer behavior.

In most of the academic studies and brand personality research conducted by practitioners, the main brand personality characteristic of a company is determined in accordance with the variance scores achieved in Exploratory Factor Analysis and this personality trait is highlighted in marketing communication activities. However, as the purpose of developing positioning strategies and communication activities is to create positive responses in consumers, brand personality dimensions should be examined in terms of their effects on consumer behavior before making a decision on the main personality trait to be communicated. In this study brand image, brand loyalty and willingness to recommend the brand to others are included as dependent variables to measure consumer behavior. In this context, the aim of this study is to investigate the effects of each dimension of brand personality on brand image, brand loyalty and willingness to recommend the brand to others in order to be able to determine if it is the trait with the highest variance that should be communicated in integrated marketing communications.

\section{Literature Review}

\section{Brand Personality}

Brand personality is "the set of human characteristics that are associated with a brand" (Aaker 1997: 347) and it is a persuasive tool to distinguish the brand from competitors at the symbolic level (Biel 1993, Sung and Kim 2010). Advertisers and brand managers know that brand personality "plays a pivotal role in consumer attitudes and purchase intentions" (Freling et al. 2011: 392). A distinctive, robust, desirable and constant brand personality is the key determinant in successfully differentiating a brand from competitors (Siguaw et al. 1999).

The brand personality concept is based on psychological trait theory and is characterized by the idea that it is the internal personality characteristic which leads people's behavior in different situations (Zentes et al. 2008). The main idea behind the theory is to "characterize individuals in terms of a comprehensive but finite and preferably small set of stable dispositions that remain invariant across situations and that are distinctive for the individual" (Zentes et al. 2008:169, Tan et al. 2004). The Big Five Model that was developed by McCrae and Costa in 1990 has become the most widely used model to describe human personality features (Achouri and Bouslama 2010, Altuna 2014). According to this model, personality is described by emotional, cognitive and behavioral elements which constitute of five dimensions: openness $(\mathrm{O})$, conscientiousness $(\mathrm{C})$, extroversion $(\mathrm{E})$, agreeableness (A) and neuroticism $(\mathrm{N})$ that are known with the abbreviation of OCEAN (Azoulay and Kapferer, 2003, Mulyangerara et al. 2009).

Brand personality literature mostly focuses on two dominant themes: diagnosing the nature of a brand's personality and examining the changes in brand attitudes and related measures as a consequence of having a distinctive, 
favorable brand personality (Freling et al. 2011:393). In the first stream of research which aim to determine the personality of specific brands, Aaker's (1997) brand personality model, which is comprised of the five dimensions competence, excitement, ruggedness, sincerity and sophistication, is widely used. Despite the criticisms mostly on its generalizability (Austin et al. 2003, Azoulay and Kapferer 2003); it has been applied in a large number of fields and cultures since 1997. Regarding the latter stream of research, brand personality has been examined in relation to various constructs in literature such as consumers' attachment styles (Swaminathan et al. 2009), brand trust (Chaudhuri and Holbrook, 2001; Sung and Kim, 2010), brand identification (Kim et al. 2001), perceived quality (Ramaseshan and Tsao, 2007), self-image congruency (Sirgy et al. 2000, Kressman et al. 2006), brand love (Delgado-Ballester et al. 2017) and brand loyalty (Kumar et al. 2006, Lin, 2010).

\section{Relationship between Brand Personality and Brand Image}

As known from past research, brands have both symbolic and functional meanings to consumers. In other words, an individual interprets a brand in two ways consisting of both functional and symbolic facets (Kressman et al. 2006, Kim et al. 2011). Functional benefits refer to the problem-solving capacity of the brand, whereas symbolic benefits are more abstract qualities that "contain an explanation as to why some consumers are willing to pay considerably more for a brand when compared to the competitor" (Kim et al. 2011:449). Among those benefits, symbolic ones are more associated with brand image and they are known to be the drivers of brand image which leads to brand preference. Consumers are known to choose brands that do not have only functional benefits but also carry a congruent image with their ideal self-image which they desire to transfer to others. Brand personality, due to its symbolic nature, is a key dimension that represents the image of brands (Bhat and Reddy 1998, Lau and Phau 2007) and a strong driver of brand equity (Keller 2003). Being cognizant of this fact, brand managers work hard in developing brand personalities to enhance brand image; to attract consumers to the brand; and create preferences to the brand as brand personality is known to ensure a stable brand image over time (Aaker 1996). Thus, it is hypothesized that:

H1: The dominant brand personality dimension has the highest effect on brand image.

\section{Relationship between Brand Personality and Brand Loyalty}

Studies have revealed that brand personality is an effective tool in building trust and loyalty. The marketing activities conducted by companies generally aim to convey the personality of a brand to consumers and hence to strengthen the communication between the brand and the consumer in a way to enhance loyalty to the brand and build brand equity (Lin 2010, Govers and Schoormans 2005). There is a limited stream of work on the relationship between brand personality 
and brand loyalty which mostly focus on the indirect and direct effects of brand personality on loyalty. Regarding the indirect effects of brand personality on loyalty, since brand personality is created in consumers' minds' as an outcome of the perception of a brand, "it can have a meaningful and significant impact on both brand trust and brand affect" (Sung and Kim 2010:643). High consumer trust and affect are shown to result in higher consumer loyalty (Chaudhuri and Holbrook 2001). In a study conducted by Kim et al. (2001), the attractiveness of brand personality showed a positive direct effect on word of mouth and an indirect effect on brand loyalty. In their study focusing on a restaurant context, Lee et al. (2009) found evidence for the indirect effects of brand personality on brand loyalty with the mediating effects of emotion and customer satisfaction. Consistent with these findings, the study of Freling and Forbes (2005:155) also shows that brand personality has a positive effect on brand loyalty. According to their study, "a strong, favorable brand personality provides emotional fulfillment and may lead to an increased willingness to continue using a given brand".

In a study examining the direct effects of brand personality on brand loyalty, results indicate that brand personality has a positive influence on brand preference, affection, loyalty and purchase intention (Mengxia, 2007). In another study with a similar research question, it was found that brand personality has an effect on respondents' loyalty to consumer goods (Kumar et al. 2006). In the study conducted on the toys and video games industry, Lin (2010) found that the competence and sophistication brand personality dimensions had a significant effect on affective loyalty whereas competence, peacefulness and sophistication showed significant effect on action loyalty. As may be seen in past research, brand personality has either a direct or an indirect effect on brand loyalty. Thus it is hypothesized that:

H2: The dominant brand personality dimension has the highest effect on brand loyalty.

\section{Relationship between Brand Personality and Willingness to Recommend the Brand to Others}

One of the few behavioral intentions measured in literature is the recommenddation of the brand to others. In the purchase-decision process, consumers often turn to others for recommendation (Punj and Staelin 1983). Especially in this communication era, where the information penetrates at a dramatic pace and the internet and social media enable the individuals to share their experiences and feelings about the brands they use; brand recommendations and word of mouth have become the "dominant forces in the marketplace" (Mangold et al. 1999, Finn et al. 2009). Therefore, marketing professionals are seeking ways to make their customers "talk about" their brands positively and "mention" their experiences amiably. Past research provides evidence that intention to recommend to others predicts company success better than satisfaction (Pingitore et al. 2007, Finn et al. 2009). Positive image is known to contribute positively to willingness to recommend to others (Assaker et al. 2011). As brand personality has a dominant effect 
on brand image, it is expected to have a significant effect on willingness to recommend to others as well. Thus it is hypothesized that,

H3: The dominant brand personality dimension has the highest effect on willingness to recommend the brand to others.

\section{Methodology}

The aim of this research is to explore whether it is the dominant or other brand personality dimension that should be highlighted as part of marketing communication strategies. Correspondingly, this study focuses on the effects of each dimension of brand personality on brand image, brand loyalty and willingness to recommend the brand to others in order to determine whether it is the dominant or other brand personality dimension which has the highest statistically significant effect on the specified dependent variables.

The research process consists of two parts: exploratory and descriptive. As part of the exploratory research process, a pre-test and a focus group session were conducted in order to generate additional adjectives to Aaker's (1997) brand personality structure, in order to reflect the personality traits in the apparel eretailing industry more accurately.

Following the exploratory process, as part of the descriptive research, Exploratory Factor Analysis (EFA) was conducted on the set of brand personality variables that consisted of both the recently generated adjectives and the original ones in Aaker's (1997) model. Following the EFA, Regression Analysis was conducted to investigate the effects of brand personality dimensions on brand image, brand loyalty and willingness to recommend the brand to others.

Subsequent to the descriptive research, in order to interpret the findings of the data analysis, to get thorough customer insight and to aid decision makers in planning their communication strategies, one final focus group discussion session was conducted.

\section{Exploratory Research Process: Pre-Test and Focus Group Discussion Sessions}

In order to determine the adjectives that would describe the brand personality of the female fashion e-retailer company included in the study (Company X), a pre-test was conducted on 700 respondents who were registered in the company website, all of whom were females. In the pre-test that consisted of an online openended questionnaire, the respondents were asked "If Company $X$ were a person, what personality characteristics would describe him/her?"

Following the pre-test, a focus-group discussion session was held to eliminate the adjectives generated in the former step and in order to "refine the research instrument" (Barbour, 2007:16). Twenty participants were invited to the session in order to avoid inadequate attendance of participants. Surprisingly, sixteen participants showed up to the session. So as not to refuse the participants who responded favorably to the management's invitation, two researchers co-moderated the focus 
session and conducted the group discussion in cooperation. The focus group discussion lasted for 105 minutes, in which funneling technique was used where the participants were encouraged to share their thoughts and feelings about the company and in the end of the session they were required to imagine Company $\mathrm{X}$ as a human being and to describe this person by using various adjectives. After the focus group discussion session, the adjectives mentioned during the discussion were compared with the results of the pre-test and those adjectives which were not mentioned in both phases were eliminated. As a result, twenty-six adjectives were added to Aaker's (1997) brand personality scale.

\section{Measures Used in the Research, Sampling Method and Data Collection}

Brand personality was measured using a 5-point scale ( $1=$ strongly nondescriptive to $5=$ strongly descriptive) that was based on Aaker's (1997) seminal model which included 68 adjectives (42 from Aaker's model and 26 from the exploratory study). In order to measure brand image (affective), the 3-item, 5-point Likert-type scale $(1=$ strongly disagree to $5=$ strongly agree) of Martinez, Montaner and Pina (2009) based on Weiss, Anderson and MacInnes (1999) and a direct question (In general, I believe that $x$ brand has a high image) was used. For brand loyalty 3-items adapted from Yoo et al. (2000) was used (5-point Likerttype scale $(1=$ strongly disagree to $5=$ strongly agree). Lastly, willingness to recommend the brand to others was measured using one 5 -point Likert-type item (I recommend this brand to others). All the negative items were reverse coded before data analysis. Due to monetary and time constraints, convenience sampling and online survey method were used in the study. A total of 4636 surveys were collected. After the elimination of incomplete and incorrectly filled surveys, data were analyzed in terms of outlier analysis (Mahalanobis distance method). As a result 4410 surveys remained for further analysis.

\section{Findings and Results}

\section{Respondent Profile}

In order to determine the sample profile and shopping frequency from Company $\mathrm{X}$, four questions were asked in the survey. The results are given in Table 1.

As seen in Table 1, the total sample consists mainly of females aged between 26-35 years; university graduates who work at private sector and who shop from Company $\mathrm{X}$ once every three months. 
Table 1. The Sample Profile and Shopping Frequency

\begin{tabular}{|l|c|c|}
\hline \multicolumn{2}{|l|}{} & Frequency (N) \\
\hline Age & 1560 & 35.6 \\
\hline $16-25$ & 1842 & 42.0 \\
\hline $26-35$ & 794 & 18.1 \\
\hline $36-45$ & 185 & 4.2 \\
\hline $46+$ & \multicolumn{2}{|l|}{} \\
\hline Education Level (last graduated) & 222 & 5.1 \\
\hline Primary School & 1153 & 26.3 \\
\hline High School & 2560 & 58.5 \\
\hline Undergraduate & 441 & 10.1 \\
\hline Graduate & 1185 & 27.1 \\
\hline Occupation & 1209 & 27.6 \\
\hline Unemployed & 902 & 20.6 \\
\hline Private sector & 259 & 5.9 \\
\hline Public sector & 80 & 1.8 \\
\hline Self-employed & 744 & 17 \\
\hline Part Time & \multicolumn{2}{|l|}{} \\
\hline Student & 28 & 0.6 \\
\hline Shopping Frequency from Company X & 0.8 \\
\hline Everyday & 34 & 1.9 \\
\hline Every third day & 82 & 3.8 \\
\hline Once a week & 164 & 22.7 \\
\hline Once a fortnight & 989 & 27.5 \\
\hline Once a month & 1198 & 16.6 \\
\hline Once in three months & 723 & 6.2 \\
\hline Once in six months & 867 & \\
\hline Once a year & 272 & \\
\hline Never shopped & \multicolumn{2}{|l|}{} \\
\hline
\end{tabular}

\section{Descriptive Statistics Results}

For descriptive statistics, mean scores and standard deviations for the 68 scale items were calculated (Appendix 1). As seen in Appendix 1, the brand personality traits with the highest mean scores are reliable, successful, clean (pure), hardworking, wholesome and sincere whereas the ones with the lowest mean scores are rugged, peasant, tough and masculine. The mean and standard deviations were also calculated for the brand image, brand loyalty and willingness to recommend the brand to others scales. As these constructs took place in the research model as dependent variables, their grand mean scores were calculated and used in subsequent analyses.

As in Table 2, all of the dependent variables show high mean scores (above the mid-point 3.00) indicating high levels of brand loyalty, brand image and willingness to recommend the brand (Company $\mathrm{X}$ ) to others. 
Table 2. Descriptive Statistics for the Dependent Variables

\begin{tabular}{|l|c|c|}
\hline Dependent Variables & Mean & Std. Dev. \\
\hline Brand Loyalty & 3.87 & 1.289 \\
\hline Brand Image & 4.20 & 0.944 \\
\hline Willingness to recommend the brand to others & 4.26 & 1.099 \\
\hline
\end{tabular}

\section{Reliability Analysis}

Before conducting any further analysis, all scales were tested for reliability using Cronbach's Alpha scores. According to the results of the reliability tests, the Cronbach's $\alpha$ score for the 68 -item brand personality scale was found to be 0.981 . Reliability analysis were repeated for the other multi-item scales: brand loyalty and brand image. The $\alpha$ scores were 0.917 and 0.924 respectively. Assessing the Alpha scores, it may be said that the internal consistency estimates for all the scales used in the study are well above the cut-off point of 0.70 as stated by Nunnally and Bernstein (1994) suggesting high internal consistency.

\section{Brand Personality Dimensions of Company X: Exploratory Factor Analysis (EFA)}

In order to examine the dimensional structure of the 68 -item brand personality scale, Exploratory Factor Analysis (EFA) was conducted and repeated until no items showed factor loadings below 0.50. The final results of EFA conducted using principal component analysis and varimax rotation emerged six factors consisting of 52 items with Total Variance Explained (TVE) of $67.76 \%$ (KaiserMeyer-Olkin $=0.983 ; \chi^{2}=155002.479 ; \mathrm{df}=1326 ; \mathrm{p}=0.000$ ). The six factors which differed from Aaker's (1997) model, were labeled as, F1: Elegant \& Gracious $\left(\mathrm{R}^{2}=49.354 ; \alpha=0.969\right) ; \mathrm{F} 2$ : Measured \& Conservative $\left(\mathrm{R}^{2}=6.238 ; \alpha=0.943\right) ; \mathrm{F} 3$ : Sincere $\left(\mathrm{R}^{2}=4.72 ; \alpha=0.907\right) ; \mathrm{F} 4$ : Excited $\left(\mathrm{R}^{2}=3.103 ; \alpha=0.874\right) ; \mathrm{F} 5$ : Tough \& Rugged $\left(\mathrm{R}^{2}=2.336 ; \alpha=0.857\right)$ and F6: Expert $\left(\mathrm{R}^{2}=2.010 ; \alpha=0.877\right)$. The factors and the loaded items may be seen in Appendix 1.

In order to evaluate the brand personality structure of Company $X$ and to determine the brand personality characteristic that identified with the company the most, descriptive statistics analyses were repeated for the factor dimensions achieved through EFA.

Table 3. Descriptive Statistics for the BP Dimensions

\begin{tabular}{|l|c|c|}
\hline Brand Personality Dimensions & Mean & Std. Dev. \\
\hline F1: Elegant \& Gracious & 4.15 & 0.824 \\
\hline F2: Measured \& Conservative & 4.30 & 0.760 \\
\hline F3: Sincere & 4.35 & 0.734 \\
\hline F4: Excited & 4.13 & 0.856 \\
\hline F5: Tough \& Rugged & 2.17 & 1.177 \\
\hline F6: Expert & $\mathbf{4 . 4 0}$ & $\mathbf{0 . 7 6 3}$ \\
\hline
\end{tabular}

As seen in Table 3, F6: Expert achieved the highest score among the six dimensions. Considering the highest mean score approach, the results show that the dominant brand personality dimension of Company $\mathrm{X}$ is Expert, followed by 
Sincere and Measured \& Conservative.

The Effects of Brand Personality Dimensions on Brand Image, Brand Loyalty and Willingness to Recommend the Brand to Others

In order to see which brand personality dimensions has a statistically significant effect on the dependent variables, regression analyses were conducted. The results of the Regression Analyses are given in Table 4.

Table 4. Results of Multiple Regression Analyses

\begin{tabular}{|c|c|c|c|}
\hline Independent Variable & $\begin{array}{c}\text { Dependent: } \\
\text { Brand Image } \\
\text { Beta (sig.) }\end{array}$ & $\begin{array}{l}\text { Dependent: } \\
\text { Brand Loyalty } \\
\text { Beta (sig.) }\end{array}$ & $\begin{array}{c}\text { Dependent: } \\
\text { Willingness to } \\
\text { Recommend } \\
\text { Beta (sig.) }\end{array}$ \\
\hline F1: Elegant \& Gracious & $0.386(0.000)^{*}$ & $0.433(0.000)^{*}$ & $0.373(0.000)^{*}$ \\
\hline F2: Measured \& Conservative & $0.162(0,000)^{*}$ & $0.022(0.426)$ & $0.045(0.109)$ \\
\hline F3: Sincere & $0.238(0.000)^{*}$ & $0.249(0.000)^{*}$ & $0.244(0.000) *$ \\
\hline F4: Excited & $-0.036(0.062)$ & $-0.046(0.035) *$ & $-0.064(0.004) *$ \\
\hline F5: Tough \& Rugged & $-0.020(0.095)$ & $0.033(0.015)^{*}$ & $0.017(0.211)$ \\
\hline F6: Expert & $0.053(0.009)^{*}$ & $0.022(0.328)$ & $0.062(0.008) *$ \\
\hline Adj. $R^{2}$ & 0.537 & 0.402 & 0.368 \\
\hline
\end{tabular}

*Statistically significant $(\mathrm{p} \leq 0,050)$

As seen in Table 4, among the six brand personality dimensions, the dimension with the highest statistically significant effect on all three dependent variables is F1: Elegant \& Gracious. Following this result the remaining highest effects are: for the dependent variable Brand Image, F3: Sincere, F2: Measured \& Conservative and F6: Expert; for the Brand Loyalty dependent variable, F3: Sincere, F5: Tough \& Rugged and F4: Excited; and for the dependent variable Willingness to Recommend the Brand to Others, F3: Sincere, F6: Expert and F4: Excited.

As the dominant brand dimension F6: Expert showed the highest mean score among the brand personality dimensions of Company X, it was expected that it would also have the highest statistically significant effect on brand image, brand loyalty and willingness to recommend the brand to others. Surprisingly, the results reveal that the personality dimension F1: Elegant \& Gracious has the highest statistically significant effect on all dependent variables. In other words, contrary to expectations, the dominant brand personality dimension (F6: Expert) does not have the highest effect on the dependent variables. Moreover, this dimension (F1) has no statistically significant effect on brand loyalty, and a minor effect on brand image and willingness to recommend the brand to others. Thus H1, H2 and H3 are not supported.

\section{Determining the Main Brand Personality Characteristic of Company X}

Conflicting with expectations, the dominant brand personality dimension did not have the highest effect on brand image, brand loyalty and willingness to 
recommend the brand to others which are the variables that are known to be highly related with marketing communication strategies. In other words, according to the results of the analyses, it seems pointless and incoherent to designate F6: Expert as the main brand personality characteristic of Company $\mathrm{X}$ to be highlighted in the marketing communication campaigns and activities of Company X.

It should be noted that in the study, in order to interpret the findings and to determine the dominant brand personality characteristic of Company $\mathrm{X}$ to be used as basis in the marketing communications strategies, an additional focus group discussion session and further EFA were conducted based on the results of the focus group session. The additional focus group session was held with eight people with different demographic characteristics. Six of the participants were currently the customers of Company $\mathrm{X}$ whereas two of them were registered subscribers on Company X's website but did not conduct any online shopping yet.

The aim of the participant recruitment strategy was to provide extensive insight from both the current and the potential customers of the company in order to determine the most effective brand personality structure to be used in marketing communication campaigns of Company $\mathrm{X}$. The focus group discussion session lasted for 95 minutes in which funneling technique was employed. The findings of the focus group discussion revealed that Company $\mathrm{X}$, which operates as an eretailer company, is perceived as a technical brand that is successful, productive, an expert and institutional. The participants highlighted the fact that these characteristics were highly identified with e-retailing. As these characteristics did not have a major effect on the dependent variables, it could be said that these are the motivation-hygiene factors for Company X. As known, Herzberg's motivationhygiene model states that hygiene factors are essential for motivation but do not result in satisfaction in the long term (Herzberg et al. 1959). However, if they are absent, they cause dissatisfaction. Hence it could be said that these characteristics are a prerequisite for e-commerce companies.

The findings of the discussion manifested that assigning F6: Expert as the main brand personality characteristic in communicating with the target market would not create any positive reaction in customers as these characteristics are expected as a default precondition rather than as a differentiating competitive characteristic. Therefore, it would be a blunder to construct the marketing communication and positioning strategies on the dominant brand personality characteristic (F6: Expert). It would not be wrong to state that being an expert is actually the point-of-parity (POP) for companies operating in e-retailing business. On the other hand the consensus of the participants was that as Company $\mathrm{X}$ is an apparel e-retailer, it is significant that it is perceived as Elegant \& Gracious as this characteristic is crucial in their preferences for apparel. In other words, basing the communication strategies of Company $\mathrm{X}$ on the brand personality characteristic Elegant \& Gracious would create competitive advantage as it would be perceived as a point-of-difference (POD) by customers. 


\section{Discussion and Conclusion}

Brand personality serves benefits to both consumers and brands. From the consumers' point of view, it "represents a modern way of expressing themselves by affirming their personalities and defining their standards of living by means of material possessions" (Jain, 2017:43). For brands, it is a tool used to "distinguish their goods or services from those of the competitors and also as a means to inform customers about the advantages they can derive from buying their respective goods or services and/or the status connotations of using them" (Jain, 2017:43). On this basis, companies invest on brand personality research to understand the personality perception of their brands by the target market and they use this personality trait as a communication tool in their marketing activities.

This study, which consists of both an exploratory and a descriptive research process, aims to determine whether the dominant brand personality dimension should be utilized as the main brand personality characteristic in positioning and marketing communication strategies. Correspondingly, the research tested for the effects of each dimension of brand personality on brand image, brand loyalty and willingness to recommend the brand to others in order to determine whether the dominant brand personality dimension would show the highest statistically significant effect on the specified dependent variables.

Results of the EFA revealed a six-factor solution (Elegant \& Gracious, Measured \& Conservative, Sincere, Excited, Tough \& Rugged and Expert) that differed from Aaker's model. Among the six factors, F6: Expert was found to have the highest mean score. Considering the highest mean score approach in determining the main personality characteristic of a brand, it could be stated that the dominant brand personality of Company $\mathrm{X}$ is Expert. In order to test the hypotheses, Multiple Regression Analyses were conducted where Brand Image, Brand Loyalty and Willingness to Recommend the Brand to Others were used as the dependent variables. As the dominant brand personality dimension was identified as Expert, it was expected that it would also show the highest statistically significant effect on the dependent variables. However, Elegant \& Gracious showed the highest statistically significant effect on all dependent variables. Thus, the hypotheses were not supported. The focus group discussion sessions also supported this finding. Hence, it could be said that Company $\mathrm{X}$ should embrace Elegant \& Gracious as the dominant brand personality characterristic to be communicated in its marketing activities.

In conclusion, the findings of this study indicate that when developing positioning and marketing communication strategies, it may not always be correct for companies to use the dominant brand personality characteristic as the main characteristic to focus on, as this characteristic may actually be the point of parity for the company and have no effect in creating positive reactions in customers. In some cases, other brand personality characteristics may create the point of difference for the company and on which the marketing communication strategies of the company should be based on. 


\section{Limitations \& Suggestions for Further Research}

As with all research, the study holds some limitations in terms of generalizability. Firstly, the data was collected only for one brand. Although this brand is a major brand with high market share and reputation in the apparel e-retailing industry the findings pertain only to this brand. Due to the time and monetary constraints, convenience sampling was used. Additionally, the survey was conducted only on registered females to the company website as the company sells only women's apparel. For researchers who are interested in the field, it is recommended to include different brands from other industries and to test the generalizability of the findings of this study. Besides, other dependent variables may be added into the research model to be tested.

\section{Acknowledgement}

This paper will be published also by ATINER in the book entitled "Turkish Studies" in 2019

\section{References}

Aaker DA (1996). Building Strong Brands. The Free Press; NY.

Aaker J (1997). Dimensions of Brand Personality. Journal of Marketing Research 134(3): 347-356.

Achouri MA, Bouslama N (2010). The Effect of the Congruence between Brand Personality and Self-Image on Consumers' Satisfaction and Loyalty: A Conceptual Framework. IBIMA Business Review: 1-16.

Altuna OK (2014). The Impact of Brand Personality on Brand Experience: A Compari- son between the Perceptions of Facebook, Twitter and Instagram Users, International Interdisciplinary Business-Economics Advancement (IIBA) Conference Proceedings July 16-19: 323-338.

Assaker G, Vinzi VE, O'Connor P (2011). Examining the Effect of Novelty Seeking, Satisfaction, and Destination Image on Tourists' Return Pattern: A Two Factor, NonLinear Latent Growth Model. Tourism Management 32(4): 890-901.

Austin JR, Siguaw JA, Matilla AS (2003). A Re-Examination of the Generaliza- bility of the Aaker Brand Personality Framework. Journal of Strategic Marketing 11(2): 7792.

Azoulay A, Kapferer JN (2003). Do Brand Personality Scales Really Measure Brand Personality? Brand Management, 11(2): 143-155.

Barbour R (2007). Doing Focus Groups, The Sage Qualitative Research Kit, Ed. Uwe Flick, Sage Publications: London, UK.

Belk RW (1988). Possessions and the Extended Self, Journal of Consumer Research 15 (2): 139-168.

Bhat S, Reddy SK (1998). Symbolic and Functional Positioning of Brands, Journal of Consumer Marketing 15(1): 32-43.

Biel A (1993). Converting Image into Equity, in Aaker, D.A. and Biel, A. (Eds), Brand Equity and Advertising: 67-82, Lawrence Erlbaum Associates: Hillsdale, NJ.

Chaudhuri A, Holbrook MB (2001). The Chain of Effects from Brand Trust and Brand 
Affect to Brand Performance: The Role of Brand Loyalty, Journal of Marketing, 65(2): 81-93.

Delgado-Ballester E, Palazon M, Pelaez-Munoz J (2017). This Anthropomorphised Brand is So Loveable: The Role of Self-Brand İntegration. Spanish Journal of Marketing (ESIC) 21(2): 89-101.

Finn A, Wang L, Frank T (2009). Attribute Perceptions, Customer Satisfaction and Intention to Recommend E-Services. Journal of Interactive Marketing, 23: 209-220.

Freling TH, Forbes LP (2005). An Empirical Analysis of theBrand Personality Effect. Journal of Product \& Brand Management 14(7): 404-413.

Freling TH, Crosno JL, Henard DH (2011). Brand Personality Appeal: Conceptua-lization and Emprical Validation. Journal of the Academy of Marketing Science, 39: 392-406.

Graeff TR (1997). Consumption Situations and the Effects of Brand Image on Consu-mers' Brand Evaluations. Psychology \& Marketing, 14(1): 49- 70.

Govers PCM, Schoormans JPL (2005). Product Personality and Its Influence on Consumer Preference. Journal of Consumer Marketing 22(4): 189-97.

Herzberg F, Mausner B, Snyderman B (1959), The Motivation to Work, Wiley, New York, NY.

Jain R (2017). Brand Personality and Brand Loyalty. International Journal of Research in Commerce and Management 8(66): 43-46.

Keller KL (2003). Strategic Brand Management ( $2^{\text {nd }}$ Ed.). Upple Saddle River, NJ: Pearson Education.

Kim CK, Han D, Par SB (2001). The Effect of Brand Personality and Brand Identification on Brand Loyalty: Applying the Theory of Social Identification. Japanese Psychological Research 43(4): 195-206.

Kim D, Magnini VP, Singal M (2011). The Effects of Customers' Perceptions of Brand Personality in Casual Theme Restaurants. International Journal of Hospitality Management, 30(2): 448-458.

Kressmann F, Sirgy MJ, Herrmann A, Huber F, Huber S, Lee D-J (2006). Direct and Indirect Effects of Self-image Congruence on Brand Loyalty. Journal of Business Research 59(9):955-64.

Kumar R, Luthra A, Datta G (2006). Linkages Between Brand Personality and Brand Loyalty: A Qualitative Study in an Emerging Market in the Indian Context. South Asian Journal of Management 13(2): 11-35.

Lau KC, Phau I (2007). Extending Symbolic Brands Using Their Personality: Examining Antecedents and Implications Towards Brand Image Fit and Brand Dilution. Psychology and Marketing, 24(5): 421-444.

Lee YK, Back KJ, Kim JY (2009). Family Restaurant Brand Personality and ITS Impact on Customer's Emotion, Satisfaction, and Brand Loyalty. Journal of Hospitality and Tourism Research, 33(3): 305-328.

Lin LY (2010). The Relationship of Consumer Personality Trait, Brand Personality and Brand Loyalty: An Empirical Study of Toys and Video Games Buyers. Journal of Product and Brand Management 19(1): 4-17.

Mangold WG, Miller F, Brockway GR (1999). Word-of-Mouth Communication in the Service Marketplace. Journal of Services Marketing 13(1): 73-89.

Martínez E, Montaner T, Pina JM (2009). Brand Extension Feedback: The Role of Advertising, Journal of Business Research 62: 305-313.

McCrae RR, Costa PT (1990). Personality in Adulthood. Guilford: New York.

Mengxia Z (2007). Impact of Brand Personality on PALI: A Comparative Research between Two Different Brands. International Management Review 3(3): 36-46.

Mulyanegara RC, Tsarenko Y (2009). Predicting Brand Preferences, an Examination of the Predictive Power of Consumer Personality and Values in the Australian Fashion 
Market, Journal of Fashion Marketing and Management 13(3): 358-371.

Nunally JC, Bernstein IH (1994). Psychometric Theory, 3rd Ed., McGraw Hill: New York, USA.

Pingitore G, Morgan NA, Rego LL, Gigliotti AA, Meyers J (2007). The Single-Question Trap. Marketing Research: A Magazine of Management and Applications 19 (Summer): 8-13.

Punj GN, Staelin R (1983). A Model of Consumer Information Search Behavior for New Automobiles. Journal of Consumer Research 9(4): 366-80.

Ramaseshan B, Tsao HY (2007). Moderating Effects of the Brand Concept on the Relationship between Brand Personality and Perceived Quality. Brand Management, 14(6): 458-466.

Siguaw J, Mattila A, Austin J (1999). The Brand Personality Scale: An Applicatio for Restaurants, Cornell Hotel and Restaurant Administration Quarterly 40(3): 48-55.

Sirgy MJ, Grewal D, Mngleburg T (2000). Retail Environment, Self-Congruity and Retail Patronage: An Integrative Model and Research Agenda. Journal of Business Research 49: 127-138.

Sung Y, Kim J (2010). Effects of Brand Personality on Brand Trust and Brand Affect. Psychology and Marketing, 27(7) July: 639-661.

Swaminathan V, Stilley KM, Ahluwalia R (2009). When Brand Personality Matters: The Moderating Role of Attachment Styles. Journal of Consumer Research, 35: 9851002.

Tan HH, Foo MD, Kwek MH (2004). The Effects of Customer Personality Traits on the Display of Positive Emotions. Academy of Management Journal 47(2): 287-96.

Weiss AM, Anderson E, MacInnis D J (1999). Reputation Management as a Motivation for Sales Structure Decisions, Journal of Marketing, 63 (October):74-89.

Yoo B, Donthu N, Lee S (2000). An Examination of Selected Marketing Mix Elements and Brand Equity, Journal of Academy of Marketing Science, 28(2):195-211.

Zentes J, Morschett D, Schramm-Klein H (2008). Brand Personality of Retailers- An Analysis of Its Applicability and Its Effects on Store Loyalty. International Review of Retail, Distribution and Consumer Research 18(2): 167-184. 
Appendix 1. Mean Values, Standard Deviations, Factor Dimensions and Loadings

\begin{tabular}{|c|c|c|c|c|c|c|c|}
\hline $\begin{array}{c}\text { Brand } \\
\text { Personality } \\
\text { Scale Items }\end{array}$ & Mean & $\begin{array}{l}\text { St. } \\
\text { Dev. }\end{array}$ & $\begin{array}{c}\text { FACTOR } \\
\text { DIM./ } \\
\text { LOADING }\end{array}$ & $\begin{array}{c}\text { Brand } \\
\text { Personality } \\
\text { Scale Items }\end{array}$ & Mean & $\begin{array}{c}\text { St. } \\
\text { Dev. }\end{array}$ & $\begin{array}{l}\text { FACTOR } \\
\text { DIM./ } \\
\text { LOADING }\end{array}$ \\
\hline Down-to-earth $(a)$ & 4.07 & 1.013 & F3 / 0,606 & Good-looking $(a)$ & 4.24 & .966 & F1 / 0.703 \\
\hline Family-oriented $(a)$ & 4.17 & 1.031 & F3 / 0.619 & Charming $(a)$ & 4.15 & 1.016 & F1 / 0.587 \\
\hline Small- town $(a)^{*}$ & 2.84 & 1.412 & F5 / 0.532 & Feminine $(a)^{* *}$ & 4.20 & 1.062 & \\
\hline Honest $(a)$ & 4.43 & .876 & F3 / 0.733 & Smooth $(a)^{* *}$ & 4.08 & 1.050 & \\
\hline Sincere $(a)$ & 4.44 & .878 & F3 / 0.729 & Outdoorsy $(a)^{* *}$ & 4.18 & 1.023 & \\
\hline $\operatorname{Real}(a)$ & 4.34 & .957 & F3 / 0.722 & Masculine $(a)$ & 2.49 & 1.394 & F5 / 0.755 \\
\hline Wholesome (a) & 4.45 & .879 & F3 / 0.694 & Peasant $(a)^{*}$ & 2.32 & 1.391 & F5 / 0.843 \\
\hline Original $(a)^{* *}$ & 4.27 & 1.009 & & Tough $(a)^{*}$ & 2.36 & 1.385 & F5 / 0.862 \\
\hline Cheerful (a) & 4.22 & .982 & F4 / 0.596 & Rugged $(a)^{*}$ & 1.88 & 1.274 & F5 / 0.843 \\
\hline Sentimental $(a)$ & 3.83 & 1.196 & F4 / 0.571 & Elegant/chic $(b)$ & 4.30 & .927 & F1/ 0.741 \\
\hline Friendly $(a)$ & 4.19 & 1.021 & F4 / 0.534 & Gracious $(b)$ & 4.28 & .961 & F1/ 0.718 \\
\hline Daring $(a)^{* *}$ & 3.91 & 1.168 & & $\begin{array}{l}\text { Noble/aristocratic } \\
\text { (b) }\end{array}$ & 4.23 & 1.009 & F1 / 0.727 \\
\hline Trendy (a) & 4.40 & .942 & $\mathrm{~F} 1 / 0.603$ & $\begin{aligned} & \text { High } \begin{array}{l}\text { quality/high } \\
\text { class }(b)\end{array} \\
&\end{aligned}$ & 4.27 & .974 & F1 / 0.700 \\
\hline Excited $(a)$ & 4.18 & 1.045 & F4 / 0.648 & Modern $(b)$ & 4.33 & .927 & F1 / 0.740 \\
\hline Spirited $(a)$ & 4.26 & 1.005 & F4 / 0.617 & Perfect $(b)$ & 4.02 & 1.109 & F1 / 0.751 \\
\hline $\operatorname{Cool}(a)^{* * *}$ & 3.55 & 1.339 & & Good $(b)$ & 4.23 & .987 & F1 / 0.564 \\
\hline Young $(a)^{* *}$ & 4.32 & .946 & & $\begin{array}{l}\text { Lovely/wonderful } \\
\text { (b) }\end{array}$ & 4.08 & 1.081 & F1 / 0.735 \\
\hline Imaginative $(a)$ & 4.15 & 1.106 & $\mathrm{~F} 1 / 0.635$ & Plain $(b) * *$ & 3.80 & 1.169 & \\
\hline Unique $(a)$ & 3.77 & 1.244 & F1 / 0.620 & Magnificient $(b)$ & 3.96 & 1.141 & F1 / 0.720 \\
\hline Up-to-date $(a)$ & 4.25 & .997 & F1 / 0.607 & $\begin{array}{l}\text { Decent/well- } \\
\text { behaved }(b)\end{array}$ & 4.34 & .949 & $\mathrm{~F} 2 / 0.615$ \\
\hline Independent $(a)^{* *}$ & 4.13 & 1.077 & & Colorful/lively $(b)$ & 4.36 & .909 & F2 / 0.501 \\
\hline Contemporary $(a)^{* *}$ & 4.22 & 1.004 & & Stylish $(b)$ & 4.26 & .995 & F1 / 0.693 \\
\hline Reliable $(a)$ & 4.53 & .836 & F3 / 0.557 & Conservative $(b)$ & 4.25 & 1.024 & F2 / 0.636 \\
\hline Hard-working $(a)$ & 4.47 & .847 & F6 / 0.513 & Naive $(b)$ & 4.00 & 1.164 & F2 / 0.638 \\
\hline Secure $(a)^{* * *}$ & 4.30 & .980 & & Easygoing $(b)$ & 4.25 & .967 & F2 / 0.632 \\
\hline Intelligent $(a)^{* *}$ & 4.23 & .992 & & Innovative $(b)$ & 4.24 & 1.006 & F1 / 0.580 \\
\hline Technical $(a)$ & 4.30 & .966 & F6 / 0.526 & $\begin{array}{l}\text { Consistent/ } \\
\text { harmonious }(b)\end{array}$ & 4.32 & .926 & $\mathrm{~F} 2 / 0.611$ \\
\hline Corporate $(a)$ & 4.33 & .944 & F6 / 0.611 & Respectful $(b)$ & 4.42 & .877 & F2 / 0.622 \\
\hline Successful $(a)$ & 4.48 & .825 & F6 / 0.541 & Tasty $(b)$ & 4.29 & .977 & F2 / 0.560 \\
\hline Leader $(a)^{* *}$ & 4.15 & 1.022 & & Clean/pure $(b)$ & 4.48 & .837 & $\mathrm{~F} 2 / 0.636$ \\
\hline Confident $(a)^{* *}$ & 4.34 & .925 & & Tolerant $(b)$ & 4.38 & .910 & F2 / 0.624 \\
\hline Upper-class $(a)$ & 3.82 & 1.169 & $\mathrm{~F} 1 / 0.596$ & $\begin{array}{l}\text { Measured/ } \\
\text { moderate } \\
\text { (b) }\end{array}$ & 4.30 & .943 & $\mathrm{~F} 2 / 0.651$ \\
\hline Glamarous $(a)$ & 3.83 & 1.166 & $\mathrm{~F} 1 / 0.722$ & Mysterious $(b)^{* * *}$ & 3.63 & 1.311 & \\
\hline Active (b) & 4.31 & 0.965 & $\mathrm{~F} 2 / 0.504$ & Energetic $(b)^{* *}$ & 4.32 & 0.958 & \\
\hline
\end{tabular}

(a) Adapted from Aaker (1997) (b)Generated in the exploratory research process

*Reverse-coded

**Items that have been excluded in EFA due to their low factor loadings below $<0.50$ 
